\title{
PENGGUNAAN MEDIA SOSIAL INSTAGRAM SEBAGAI STRATEGI PEMASARAN (STUDI KASUS PADA AKUN RROUTDOORGEAR_OFFICIAL)
}

\author{
SAMPIR ANDREAN SUKOCO* \\ MOH. RIZAL HIDAYATULLAH \\ Program Studi Ilmu Administrasi Niaga \\ Sekolah Tinggi Ilmu Administrasi Pembangunan Jember \\ *Email: andre@stiapembangunanjember.ac.id
}

\begin{abstract}
ABSTRAK
Aplikasi instragram adalah aplikasi yang paling populer yang dapat digunakan untuk berbagi foto dan juga video. Faktor inilah yang manjadi alasan kenapa Instagram memiliki banyak manfaat bagi pelaku bisnis. Produk yang dijual dapat dipasarkan melewati fitur-fitur yang terdapat pada akun Instagram.

Metode penelitian ini menggunakan metode kualitatif studi kasus dengan cara mendeskripsikan apa yang dilakukan RR Outdoor Gear dalam melakukan strategi pemasaran melalui instagram rroutdoorgear_official.

Teknik penentuan informan menggunakan metode purposive, informan untuk penelitian ini berjumlah 3 orang yang dipilih peneliti karena memiliki kompetensi dibidangnya. Pengumpulan data dilakukan melalui observasi, wawancara, dan dokumentasi. Metode analisis data dilakukan dengan tiga cara yaitu Data Condensation, Data Display, dan Conclusion Drawing atau Verifications.
\end{abstract}

RR Outdoor Gear adalah bisnis yang menjual perlengkapanperlengkapan pendakian (naik gunung) yang berdiri tahun 2015. Saat ini RR Outdoor Gear sudah merambah kebisnis yang lain, diantaranya persewaan (rental) alat-alat gunung, perbaikan/reparasi alat-alat gunung, dan Trip Organizer. Strategi pemasaran RR Outdoor Gear melalui akun instagram dari rroutdoorgear_official dilakukan dengan menggunakan fitur-fitur instagram diantaranya strategi posting produk (feed instagram), penggunaan hashtag, penggunaan insta story (highlights), serta DM (Direct Message). Fitur yang ada dalam instagram tersebut dijadikan alat RR Outdoor Gear dalam memasarkan produk yang dijual, baik penjualan barangnya (pakaian/perlengkapan alat-alat gunung), maupun penjualan jasanya (persewaan, reparasi/perbaikan, dan trip organizer).

Kata Kunci: Media Sosial, Instagram, Strategi Pemasaran 


\section{PENDAHULUAN}

Bisnis tidak bisa lepas dari setiap kehidupan manusia. Bisnis merupakan kegiatan-kegiatan yang bertujuan untuk bisa menghasilkan keuntungan yang dilakukan oleh perorangan maupun oleh kelompok.

Selama ada kebutuhan dan permintaan, maka kegiatan bisnis akan selalu ada untuk dilakukan. Oleh karena itu, jika aktivitas bisnis dimaknai sebagai kegiatan yang sifatnya adalah untuk memperoleh keuntungan, maka sudah tentu keberadaan bisnis itu dimulai dari (sejarahnya) manusia ada.

Kegiatan bisnis memang akan selalu ada disetiap kehidupan manusia, baik dimanapun tempatnya, skala bisnisnya maupun macam bisnis yang dijalankan oleh manusia itu sendiri. Saat ini aktivitas bisnis sudah mulai berubah. Perjalanan bisnis konvensional sudah beralih menjadi aktivitas bisnis digital karena perkembangan internet (Sukoco, 2018:124).

Perjalanan internet hadir dimulai sejak adanya proyek dari ARPAnet pada tahun 1969 oleh Amerika Serikat melalui Departemen
Pertahanannya. Dunia Pendidikan yang pertama kali mengkoneksikan dengan proyek ARPAnet adalah UCLA. Awal mula dikoneksikan kepada 4 site, diantaranya adalah UCLA, lalu ada Stanford Research Institute, ada lagi kampus UC Santa Barbara, dan yang terakhir adalah University of Utah. Penyambungan internet tersebut sebagai kepentingan pendidikan yang memudahkan pertukaran-pertukaran pengetahuan antar perguruan tinggi/kampus. Setelah fenomena tersebut terjadi, berlanjut pada tahun 1980 dimana ARPAnet terpecah menjadi dua bagian. Dua bagian tersebut adalah ARPAnet dan yang kedua adalah Milnet. Milnet sendiri merupakan jaringan khusus kemiliteran. Pada mulanya jaringan tersebut bernama DARPA lalu berubah nama menjadi Internet (Supardi, 2009:2).

Saat ini kita tahu, internet dalam perkembangannya tidak hanya digunakan oleh militer Amerika. Saat ini internet sudah digunakan semua lini kehidupan manusia. Internet dipakai dalam kehidupan sehari-hari, baik itu digunakan sebagai alat 
komunikasi sampai ke bisnis. Dulu orang jika ingin berkomunikasi harus secara langung dengan cara face to face. Dengan kehadiran internet, orang tidak perlu ketemu langsung untuk tatap muka. Hanya membutuhkan perangkat smart phone untuk bisa berkomunikasi. Begitu juga dengan aktivitas bisnis.

Kehadiran jaringan internet memang telah menghadirkan suatu kegembiraan, gairah, dan kemudahan baru bagi masyarakat. Sebuah mode interaksi sosial baru telah muncul pada abad ini dan cukup merubah secara menyeluruh cara hidup manusia. Jumlah pengguna internet juga semakin meningkat dari tahun ke tahun. Semua itu karena ditambah adanya beberapa media sosial seperti Facebook, Youtube, Twitter, dan Instagram. Layanan gratis yang bisa diakses oleh masyarakat berbagai negara tidak terkecuali Indonesia (Sudibyo, 2019:1).

Instagram adalah satu media sosial yang memiliki pengaruh penting dalam aktivitas bisnis modern. Aplikasi ini adalah aplikasi yang paling populer yang dapat digunakan untuk berbagi foto dan juga video. Faktor inilah yang manjadi alasan kenapa Instagram memiliki banyak manfaat bagi pelaku bisnis untuk membangun suatu pemasaran. Produk yang dijual dapat diupload dan dipublikasikan melewati akun Instagram kepada para konsumen maupun calon konsumen.

RR Outdoor Gear dalam menjalankan aktivitas bisnis juga menggunakan aplikasi instagram untuk memasarkan produk yang dijual. RR Outdoor adalah bisnis yang menjual berbagai perlengkapan pendakian atau apparel (pakaian), persewaan alat-alat pendakian, perbaikan/reparasi alat-alat gunung, dan juga jasa perjalanan (trip organizer). Keempat bisnis tersebut merupakan bisnis yang dijalankan oleh RR Outdoor Gear.

RR Outdoor Gear berdiri pada tahun 2015 bulan November. Bisnis ini didirikan oleh pemuda kelahiran 16 April 1994 yang bernama Reza Rivaldi. Perjalanan bisnis RR Outdoor Gear diawali ketika Reza Rivaldi masih menjadi karyawan rumah makan Seafood. Pada tahun tersebut gaji yang diperoleh dari 
menjadi karyawan rumah makan disisihkan untuk modal membeli perlengkapan gunung dan dijual kembali. Dalam kurun waktu 4 bulan Reza menjalani 2 rutinitas antara menjadi karyawan dan bisnis kecilkecilan. Ketika itu Produk yang dijual dionlinekan melalui media sosial lalu transaksi dilakukan menggunakan cara COD (Cash on Delivery).

COD merupakan salah satu metode pembayaran dalam bisnis online dimana pembeli melakukan pembayaran kepada penjual pada saat pengiriman. Dengan kata lain COD dapat diartikan sebagai kesepakatan antara pembeli dengan penjual untuk melakukan pembayaran ketika barang yang dibeli sudah sampai di alamat tujuan. Sehingga dalam cara COD ini pembeli dapat memeriksa terlebih dahulu produk yang sudah dibelinya.

Pada bulan ke 5 menjadi karyawan rumah makan Seafood, Reza Rivaldi akhirnya memilih untuk resign dan fokus berjualan produk perlengkapan gunung. Disitulah bisnis penjualan alat-alat gunung mulai fokus untuk dikembangkan. Dalam perjalanan bisnis RR Outdoor yang didirikan pada tahun 2015 hingga sekarang, perkembangan roda bisnis RR Outdoor Gear tidak hanya fokus pada penjualan perlengkapan gunung. Saat ini RR Outdoor Gear sudah merambah ke bisnis yang lain, diantaranya persewaan (rental) alatalat gunung, perbaikan/reparasi alatalat gunung, dan Trip Organizer. Bisnis tersebut semuanya masih berkecimpung di lini alat-alat pendakian gunung.

RR Outdoor Gear sendiri memanfaatkan instagram sebagai media pemasaran bisnis. Instagram memiliki beberapa fitur yang dapat dimanfaatkan oleh akun bisnis dalam menjual produk. Feed dapat digunakan sebagai sarana sharing foto dan beberapa informasi tentang produk, sedangkan Instagram Story (Insta Story) dapat dimanfaatkan untuk membagikan testimoni maupun informasi produk-produk baru. Ada juga Highlight Instagram Story yang bisa digunakan untuk memudahkan pengguna lain (konsumen) untuk mencari info tentang produk. Selain itu juga ada 
fitur hashtag (tagar) yang dapat digunakan untuk menjangkau lebih banyak audience untuk mendapat banyak view dalam setiap pencarian oleh pengguna lain (Stiletto dan Afandy, 2019:6).

RR Outdoor Gear juga menggunakan fitur-fitur tersebut seperti feed, Instagram Story, Highlight, dan hashtag. Fitur instagram lain yang dimanfaatkan oleh RR Outdoor Gear adalah penggunaan DM (Direct Message). Beberapa fitur tersebut digunakan untuk memasarkan bisnis RR Outdoor Gear diantaranya penjualan perlengkapan produk pendakian, persewaan, perbaikan/reparasi dan bisnis trip organizer.

Strategi dalam memasarkan produk (barang dan jasa) tersebut menggunakan tiga akun instagram diantaranya rroutdoorgear_official, rroutdoorgear_catalog, dan juga akun rr_trip.organizer. Untuk akun yang rroutdoorgear_official digunakan untuk memasarkan semua lini bisnis, sedangkan untuk akun instagram rroutdoorgear_catalog sendiri khusus digunakan untuk penjualan produk (catalog dari produk yang dijual), dan untuk akun rr_trip.organizer khusus digunakan untuk memasarkan jasa trip organizer.

Empat lini bisnis RR Outdoor Gear tidak memiliki akun instagram khusus (tiap bisnis satu akun). Bahkan terdapat satu akun instagram yang digunakan untuk beberapa lini bisnis seperti akun instagram rroutdoorgear_official. Pemasaran yang dilakukan pada tiap lini bisnis digabung pada akun tersebut. Hal ini menyebabkan pemasaran yang dilakukan pada tiap lini bisnis kurang begitu maksimal.

Akun instagram RR Outdoor Gear, yaitu rroutdoorgear_official pada tahun 2019 bulan Mei pernah mencapai 5.000 followers. Karena akun ini terkena hack pada bulan Juni 2019 sampai Agustus 2019 menurun drastis sampai mencapai 412 followers. Usaha RR Outdoor Gear mengembalikan followers terus dilakukan sehingga pada saat ini (November 2020) mencapai 1.401 followers. RR Outdoor Gear terus membangun dan mengembalikan jumlah followers sampai target semula. 
Beberapa fenomena diatas menjadi tantangan tersendiri bagi RR Outdoor Gear untuk memasarkan bisnisnya melalui akun instagram. Pertumbuhan followers pada akun instagram yang dimiliki oleh RR Outdoor Gear juga tidak naik secara signifikan. Padahal target yang ingin

\section{TINJAUAN PUSTAKA}

\subsection{Manajemen Pemasaran}

Manajemen pemasaran saling berkaitan dengan semua usaha menciptakan nilai bagi pelanggan dan membangun antara hubungan pelanggan yang menguntungkan. Pemasaran dimulai dengan cara memahami kebutuhan dan keinginan konsumen, memutuskan tujuan pemasaran yang dapat dilayani organisasi dengan sangat baik, dan mengembangkan proposisi nilai yang meyakinkan dimana organisasi dapat memenangkan, mempertahankan, dan juga menumbuhkan sasaran konsumen. Jika organisasi dapat melakukan hal ini dengan baik, maka organisasi tersebut akan meraih pangsa pasar, keuntungan, dan ekuitas pelanggan yang baik. (Kotler dan Armstrong, 2008: 8). dicapai oleh RR Outdoor Gear memiliki 5.000 followers aktif. Berdasarkan latar belakang diatas, maka rumusan masalah penelitian ini adalah bagaimana penggunaan media sosial rroutdoorgear_official sebagai strategi pemasaran RR Outdoor Gear?

Menurut Cannon dkk (2008:39) proses dalam manajemen pemasaran adalah suatu proses perencanaan aktivitas pemasaran, pengarahan implementasi rencana-rencana tersebut, dan pengelolaan seluruh rencana-rencana tersebut. Perencanaan, implementasi, dan pengelolaan merupakan poin-poin yang dibahas dalam manajemen pemasaran. Perencanaan strategi pemasaran artinya menemukan berbagai peluang menjanjikan dan menyusun strategi pemasaran yang menguntungkan. Dalam manajemen pemasaran membahas tentang strategi pemasaran yaitu menentukan pasar target dan bauran pemasaran yang terkait. Strategi tersebut merupakan gambaran mengenai yang akan dilakukan oleh perusahaan pada 
pasar. Dibutuhkan dua bagian yang saling berkaitan yaitu pasar target dan bauran pemasaran.

\subsection{Strategi Pemasaran}

Rahmat (2019:2) dalam bukunya menjelaskan secara umum istilah strategi yaitu suatu garis besar haluan dalam melangkah untuk bisa mencapai sasaran yang sudah diharapkan. Melihat konteks kebelakang, bahwa strategi berasal dari kata benda dan kata kerja dari bahasa Yunani. Strategi berasal dari kata benda strategos yang terdiri dari gabungan kata stratos (militer) dengan ago (memimpin). Sedangkan jika melihat dari kata kerja menunjukkan bahwa kata ini berasal dari kata stratego yang memiliki makna merencanakan. Sejarah mengatakan bahwa istilah strategi ini pertama kali dipakai untuk kepentingan militer dan didefinisikan sebagai suatu seni dalam merumuskan cara peperangan. Seiring perkembangan waktu konsep strategi dapat dimaknai dan dipakai dalam berbagai sektor.

Strategi perusahaan adalah pola keputusan dalam perusahaan yang menentukan sasaran, maksud atau tujuan yang dapat menghasilkan kebijaksanaan utama dan juga dapat merencanakan untuk pencapaian tujuan serta merinci jangkauan bisnis yang akan dicapai oleh perusahaan. Setelah mengetahui rumusan strategi perusahaan secara umum maka selanjutnya akan melihat pengertian strategi pemasaran. Definisi strategi pemasaran adalah memilih dan menganalisa pasar sasaran yang merupakan suatu kelompok orang yang ingin dicapai oleh perusahaan dan menciptakan suatu bauran pemasaran yang baik dan yang dapat memuaskan pasar sasaran tersebut (Alma, 2014: 195).

Pemasaran adalah serangkaian proses baik itu untuk menciptakan, untuk mengkomunikasikan dan memberikan nilai kepada pelanggan untuk mengelola hubungan baik konsumen dengan cara yang menghasilkan berbagai pihak, yang memiliki suatu kepentingan tertentu terhadap perusahaan. Pemasaran itu sendiri adalah fungsi yang memiliki kontak yang paling besar dengan lingkungan luar, padahal perusahaan hanya memiliki kendali yang terbatas 
terhadap lingkungan luar (eksternal). Pemasaran juga memiliki tujuan yaitu untuk menarik perhatian pembeli dalam menerima atau minimal melihat produk yang ditawarkan. Maka dari itu sesungguhnya pemasaran itu sendiri memainkan peranan yang begitu utama dalam pengembangan suatu strategi (Saleh dan Said, 2019:1).

\subsection{Media Sosial}

Media sosial adalah kelompok dari aplikasi berbasiskan internet yang dibangun atas dasar ideologi dan sarana teknologi web yang memungkinkan terciptanya media interaktif. Media sosial mampu menghadirkan serta mentranslasikan cara berkomunikasi baru, dengan teknologi yang sama sekali berbeda dari media konvensional (Sulianta, 2015:6).

Karakteristik yang ada pada media sosial tentu memiliki sisi positif dan sisi negatif. Karakteristik tersebut dapat diambil sebagai bagian dari strategi pemasaran melalui media sosial. Terlebih pada karakteristik jejaring relasi. Pelaku bisnis dalam memasarkan produknya tentu sangat membutuhkan jaringan yang luas untuk menawarkan. Melalu media sosial yang mayoritas bersifat gratis tentu para pemasar memiliki keuntungan tersendiri.

Media sosial selain memiliki karakteristik yang unik seperti penjelasan diatas juga memiliki jenis-jenisnya. Secara garis besar ada 6 jenis media sosial (Hutahayan, 2019:58) :

a. Proyek kalaborasi : situs web ini dapat memungkinkan pengguna untuk dapat mengubah dan, menambah, atau menghapus konten di situs web ini.

b. Blog dan Microblog : dimana penggunaanya lebih bebas dalam hal mengekspresikan sesuatu di blog seperti berkomentar bebas terhadap pengguna akun lainnya.

c. Konten : pengguna situs web ini berbagi konten media, seperti video, ebook, dan gambar.

d. Situs jejaring sosial : aplikasi yang sangat memungkinkan pengguna untuk membuat informasi pribadi, sehingga 
mereka dapat terhubung dengan orang lain.

e. Virtual game world : dunia virtual tempat para pengguna atau pemainnya berkumpul dan berinteraksi, baik dengan pemain lainnya maupun dengan obyek maya yang tersedia dalam dunia tersebut.

\subsection{Instagram Marketing}

Instagram merupakan media sosial untuk mengunggah gambar atau video. Saat ini aplikasi ini juga berada dibawah manajemen facebook. Oleh karena itu jika kita melihat banyak sekali kesamaan antara instagram, facebook, dan juga whatssap karena dibawah satu manajemen. Namun pada aplikasi instagram sampai sekarang masih tidak bisa untuk digunakan mengirim sebuah dokumen. Aplikasi ini memudahkan setiap pengguna untuk mengupload foto setiap kejadian yang ingin disampaikan kepada pengguna lain (Hidayatullah, 2018:99).

Instagram juga merupakan media aplikasi yang dapat digunakan untuk melakukan bisnis. Khususnya pada pengenalan produk dan strategi pemasaran produk. Pemasar dapat mengunggah foto maupun video beserta deskripsi tentang produk, sehingga konsumen/calon pembeli dapat melihat-lihat akun intagram. Hal ini seperti melihat katalog pada pemasaran konvensional, hanya saja dalam hal ini katalog produk sudah masuk pada akun intagram. Pemasaran melalui intagram juga dapat dilakukan melalui DM/pesan yang langsung dikirimkan kepada sasaran yang dituju.

Pada tahun 2016, instagram mengumumkan bahwa mereka merilis instagram For Busines. Dengan fitur ini, sebuah bisnis bisa membuat sebuah profil bisnis gratis. Dengan profil bisnis, sebagai pemilik bisnis dapat memilih bagaimana ingin pelanggan mereka dapat menghubungi mereka; baik melalui telepon, SMS, ataupun email dengan tombol kontak dan mendapat petunjuk arah. Profil bisnis juga memungkinkan untuk melihati insight dan kemampuan untuk mempromosikan dan fitur promote pada instagram memperbolehkan penggunanya untuk menjadikan 
postingan sebagai ads atau iklan di aplikasi instagram. Ads tentunya membantu produsen untuk berhubungan dengan pelanggan bisnis. Produsen pengguna instagram for business tinggal memilih salah satu postingan yang sudah diposting di instagram dan menambahkan action button lalu bisa memilih target audience dan memperbolehkan instagram menyarankan target audience untuk produk yang dijual. Selain itu, postingan tersebut akan dipromosikan sebagai iklan selama periode yang sudah dipilih (Suratman dkk, 2019:48).

Beberapa alasan itulah yang menyebabkan instagram digunakan sebagai media pemasaran oleh pelaku bisnis. Banyak pelaku bisnis yang memanfaatkan instagram untuk memperoleh pangsa pasar yang luas, sehingga diharapkan dapat untuk meningkatkan penjualan produk yang ditawarkan. Helianthusontri (2020:3) menjelaskan ada tahap awal dalam melakukan instagram marketing. Tahap-tahap yang harus dilakukan oleh pemasar diantaranya adalah : a. Membuat dan menyiapkan profil instagram.

b. Meningkatkan dari jumlah pengikut di instagram.

c. Sebagai media promosi produk yang ditawarkan.

Strategi pemasaran yang dilakukan secara daring/online menggunakan digital marketing menjadikan jangkauan pemasaran lebih luas dibandingkan dengan strategi lama (pemasaran secara konvensional). Dalam memasarkan menggunakan online khususnya instagram dapat menjangkau konsumen luar kota atau bahkan bisa sampai luar pulau. Oleh karena itu kesempatan dalam memperoleh penjualan yang baik dan mendapatkan untung maksimal lebih berpotensi dengan menggunakan media online khususnya instagam.

Terdapat strategi pemasaran instagram online secara organik. Penjualan instagram secara organik merupakan cara penjualan yang sifatnya tanpa mengeluarkan biaya yang mahal atau justru bisa gratis. Dalam metode ini ada beberapa hal yang harus diperhatikan dan dilaksanakan. Dibawah ini adalah 
strategi pemasaran melalui instagram dengan cara organik memaksimalkan tampilan akun instagram (Ibad, 2020: 119) :

\section{a. Foto profil}

Foto profil sangat penting karena pertama kali pengguna lain melihat akun pemasar adalah dengan melihat foto profil yang digunakan. Dalam instagram bisnis, foto profil yang paling baik adalah menggunakan foto profil logo brand toko.

b. Deskripsi toko

Deskripsi toko dapat ditulis dengan jargon-jargon menarik dan juga informasi yang lengkap mengenai pelayanan (jam operasional, waktu pengiriman, dan sebagainya).

c. Gambar postingan

Gambar produk yang baik akan lebih menarik jika ditambahkan dengan fitur watermark dari logo brand toko. Penambahan frame juga dapat membuat tampilan lebih menarik. Ketika posting gambar atau video, produk wajib ditambahkan secara detail deskripsi. Deskripsi/bio berisi informasi lengkap produk. Hal ini dapat membantu calon konsumen untuk yakin dalam membeli (meyakinkan).

Strategi pemasaran instagram sangat dibutuhkan sekali untuk mengoptimalkan kinerja pemasaran. Ada beberapa langkah bagaimana aplikasi instagram sebagai sarana penjualan. Menurut Politwika (2015:82) diantaranya adalah:

a. Membuat profil instagram Profil instagram harus dibuat dengan username yang menarik dan mudah untuk diingat oleh pengguna akun lain. Profil ini sebagai salah satu branding bisnis.

b. Logo Bisnis

Logo ini dapat dipajang sebagai display picture. Logo harus dibuat sebagus/sebaik mungkin dan menarik.

c. Deskripsi pada profil

Deskripsi harus dibuat dengan sangat jelas tetapi tidak terlalu panjang agar pembaca dengan cepat bisa 
memahami. Deskripsi harus terlihat profesional.

d. Unggah foto/video

Foto dan video tampilan yang kreatif/menarik. Dalam cara posting foto dan video harus resolusi tinggi agar tampilan tidak pecah saat diunggah. Unggah foto/video harus sesering mungkin pada jam yang tepat.

e. Hashtag

Hashtag adalah kata kunci dalam pencarian instagram. Pemasar dapat menambahkan hashtag sesuai dengan yang dibutuhkan.

Beberapa paltform media sosial menawarkan upaya secara gratis

\section{METODE PENELITIAN}

Metode penelitian ini menggunakan metode kualitatif studi kasus dengan cara mendeskripsikan apa yang dilakukan RR Outdoor Gear dalam melakukan strategi pemasaran melalui akun instagram rroutdoorgear_official. Untuk teknik penentuan informan menggunakan metode purposive, informan untuk penelitian ini berjumlah 3 orang yang maupun secara berbayar. Hal ini harus dapat disesuaikan dengan kemampuan pelaku bisnis. Instagram memang adalah salah satu media gratis yang bisa dimanfaatkan dan dapat secara efektif untuk dijalankan. Potensi instagram untuk pemasaran menunjukkan bahwa $80 \%$ pengguna media sosial ini mempengaruhi keputusan pembelian mereka. Strategi penting untuk menggunakan aplikasi ini adalah dengan cara beralih ke akun profesional atau instagram bisnis, dan yang kedua yang dapat dilakukan adalah optimalisasi profil bisnis. (Nofriansyah, 2020:55).

dipilih peneliti karena memiliki kompetensi dibidangnya.

Pengumpulan data dilakukan melalui observasi, wawancara, dan dokumentasi. Metode analisis data dilakukan dengan tiga cara yaitu Data Condensation, Data Display, dan Conclusion Drawing atau Verifications. 


\section{HASIL PENELITIAN DAN PEMBAHASAN}

RR Outdoor Gear berdiri pada tahun 2015. Bisnis ini didirikan oleh Reza Rivaldi. Nama RR Outdoor Gear diambil dari awal huruf nama lengkap pemilik. $\mathrm{R}$ berarti Reza dan $R$ yang kedua adalah Rivaldi. Nama tersebut disingkat menjadi RR. Untuk kata Outdoor Gear sendiri memiliki arti perlengkapan luar ruangan. RR Outdoor Gear adalah bisnis yang menjual perlengkapanperlengkapan pendakian (naik gunung).

Saat ini RR Outdoor Gear sudah merambah kebisnis yang lain, diantaranya persewaan (rental) alatalat gunung, perbaikan/reparasi alatalat gunung, dan Trip Organizer. RR Outdoor Gear menggunakan 3 akun instagram untuk melakukan strategi pemasaran diantaranya adalah menggunakan akun yang bernama rroutdoorgear_official, juga ada akun rroutdoorgear_catalog, serta akun rr_trip.organizer.

Akun rroutdoorgear_official digunakan RR Outdoor Gear untuk memasarkan semua lini bisnisnya diantaranya penjualan, persewaan, perbaikan/reparasi, dan juga trip organizer. Untuk akun yang bernama rroutdoorgear_catalog hanya khusus digunakan untuk memajang produkproduk gunung yang dijual. Dalam akun ini tidak memasarkan bisnis persewaan, perbaikan, dan trip organizer, sedangkan untuk akun rr_trip.organizer khusus digunakan untuk memasarkan pelayanan jasa kegiatan trip organizer. Jadi pada dasarnya hanya ada dua akun yang khusus pada satu lini dan yang satu akun digunakan untuk semua lini bisnis.

Sejak dibuat pada tahun 2015 Akun rroutdoorgear_official sampai sekarang sudah memiliki 1.401 pengikut. Sebenarnya akun ini pernah mencapai 5.000 pengikut. Karena terkendala pada tahun 2019 ada yang hack (dari bulan Juni 2019 sampai Agustus 2019) membuat pengikut akun instagram RR Outdoor Gear menurun drastis hingga mencapai 412. Setelah akun bisa dikembalikan normal pada bulan September 2019 oleh RR Outdoor Gear, kini pengikut instagram mulai naik perlahan hingga mencapai 1.401 pengikut. 
Akun instagram ini adalah akun pertama kali RR Outdoor Gear dalam membuka usaha/bisnis penjualan perlengkapan gunung. Akun ini digunakan untuk memasarkan seluruh aktivitas kegiatan bisnis RR Outdoor Gear dari mulai penjualan, persewaan, perbaikan/reparasi, dan trip organizer. Semua lini bisnis tersebut sengaja dijadikan satu pada akun ini karena dijadikan identitas keseluruhan bisnis yang dilakukan RR Outdoor Gear.

Foto yang dijadikan profil dalam akun rroutdoorgear_official merupakan gambar logo dari bisnis RR Outdoor Gear. Gambar logo tersebut terdiri dari gambar gunung melingkar, pohon cemara, dan gambar jalan. Ketiga gambar tersebut memiliki makna yaitu "apa yang ada dialam bebas/terbuka khususnya pegunungan". Sesuai dengan bisnis yang dijalankan oleh RR Outdoor Gear yang mengusung bisnis yang berkaitan dengan alat-alat pendakian termasuk bisnis jasa antar perjalanan untuk naik gunung. Dalam gambar profil tersebut juga terdapat tulisan RR Outdoor Gear. RR merupakan singkatan nama dari pemilik yaitu
Reza Rivaldi, sedangkan Outdoor Gear adalah makna dari perlengkapan pendakian.

Profil akun yang dibuat dengan logo RR Outdoor Gear memiliki tujuan agar pengikut atau calon pengikut akun ini dapat langsung melihat dan memahami bahwa akun instagram tersebut merupakan akun bisnis yang menjual alat-alat gunung/peralatan untuk pendakian. Ditambah tulisan Outdoor Gear yang artinya perlengkapan luar ruangan. Dengan menggunakan gambar logo dan tulisan Outdoor Gear, diharapkan dapat memudahkan para konsumen yang tertarik untuk mencari produk perlengkapan gunung mampir ke akun tersebut. Ketika konsumen melakukan pencarian di aplikasi instagram dan melihat profil, maka konsumen langsung paham bahwa akun tersebut berkaitan dengan perlengkapan gunung. Diharapkan calon konsumen tersebut pada nantinya dapat mengikuti rroutdoorgear_official atau melihat-lihat dan akhirnya bisa membeli. Profil dipasang gambar logo RR Outdoor Gear yang identik dengan perlengkapan gunung, atau 
dapat dikatakan sebenarnya strategi ini merupakan simbol awal untuk dijadikan alat pemasaran pada profil instagram.

Profil atau yang bisa disebut sebagai bio merupakan cara menciptakan kesan pertama untuk pengguna akun lain. Bio pada Instagram memberikan 150 karakter untuk menunjukkan kepada pengguna lain tentang profil instagram (bisnis), apa yang ditawarkan, dan mengapa konsumen lain harus melirik brand atau produk yang dijual. Oleh karena itu, RR Outdoor Gear melakukan bentuk kreatifitas untuk membuat bio tentang brand atau bisnis dengan benar. Dengan bio Instagram ini dapat memastikan bahwa profil instagram memberikan gambaran yang akurat dan menarik dari brand atau bisnis di Instagram.

Deskripsi atau yang biasa disebut bio digunakan oleh RR Outdoor Gear untuk menerangkan keseluruhan lini bisnis. Deskripsi yang ditulis dalam akun rroutdoorgear_official diantaranya terdiri dari nama RR Outdoor Gear Official, lalu ada penjelasan penjualan perlengkapan pakaian luar ruangan, persewaan, dan jasa trip organizer. Dalam deskripsi akun tersebut juga mencantumkan akun instagram RR Outdoor Gear yang lain. Selain itu juga tertera No $\mathrm{Hp}$ yang bisa dihubungi. No $\mathrm{Hp}$ dicantumkan dalam deskripsi agar konsumen yang ingin bertanya lebih detail tentang barang yang dijual dapat segera menghubungi penjual. Lalu pada bawah sendiri dalam bio tersebut ditulis alamat lengkap RR Outdoor Gear yang berada di Jl. Durian No. 26 Tanggul Wetan Kecamatan Tanggul Kabupaten Jember.

Keseluruhan deskripsi diatas yang ditulis oleh RR Ooutdoor Gear dalam bio memperlihatkan bahwa akun tersebut merupakan akun resmi. Penjelasan lengkap (bio) untuk menghindari keraguan konsumen apakah akun tersebut resmi milik RR Outdoor Gear atau bukan. Selain itu digunakan sebagai strategi profil instagram untuk memberikan gambaran yang akurat dan menarik dari brand atau bisnis RR Outdoor Gear. 
Strategi yang dilakukan selain menampilkan profil yang lengkap adalah juga dengan posting (feed instagram), baik berbentuk foto maupun video. Foto yang diupload berkaitan dengan aktivitas semua lini bisnis. Melihat memang akun ini tidak digunakan khusus untuk satu bisnis. Foto-foto yang diposting diantaranya kegiatanan di gunung, produk-produk RR Outdoor Gear, perbaikan alat-alat gunung, persewaan alat-alat gunung, info open trip, tips perjalanan naik gunung dan ekspedisi gunung tertinggi.

Akun ini juga tidak hanya mengupload foto, tetapi juga video. Unggahan Video yang ditampilkan diantaranya adalah video tentang tips-tips perjalanan, tips memasang tenda dengan benar, dan juga videovideo keseruan kegiatan ketika digunung. Tampilan video itu memiliki beberapa sasaran dan tujuan. Sasaran pertama untuk pendaki pemula dan sasaran kedua untuk orang-orang yang memang sudah hobi melakukan perjalanan naik gunung. Tujuannya juga berbeda-beda. Video aktivitas keseruan naik gunung ditujukan untuk pendaki pemula agar mereka memiliki ketertarikan untuk naik gunung. Pendaki pemula tidak akan dapat naik gunung tanpa perlengkapan gunung seperti baju gunung, jaket gunung, tenda, sepatu gunung dan sebagainya. Dengan begitu diharapkan setelah melihat video keseruan naik gunung tersebut, para pendaki pemula pada akhirnya ingin membeli produk-produk yang dijual oleh RR Outdoor Gear. Sedangkan video yang ditujukan kepada orang-orang yang sudah berpengalaman naik gunung memiliki tujuan agar mereka menambah perlengkapan gunung yang belum dimilikinya, baik sewa maupun membeli produk.

RR Outdoor Gear dalam melakukan upload foto/video juga melihat waktu yang strategis. Jadi tidak sembarangan dalam menentukan waktu upload. Waktu yang sering digunakan untuk upload foto/video produk-produk yang ditawarkan pada waktu jam sebelum orang sibuk pergi kekantor atau kesekolah dan pada waktu sebelum orang-orang pulang kerja/sekolah. 
Ini adalah waktu kesempatan agar pengguna lain dapat melihat-lihat instagram karena pada jam tersebut masih senggang diantara pukul 06.00 WIB - pukul 07.00 WIB. Setelah itu akan melakukan upload foto/video pada sekitar pukul 16.00 WIB pukul 17.00 WIB. Karena pada waktu sore hari ini banyak orangorang yang sudah memiliki waktu senggang.

Foto/Video yang diupload oleh akun intagram ini tersebut juga menambahkan hashtag. Hashtag berasal dari kata bahasa inggris yang jika diterjemahkan dalam bahasa Indonesia memiliki makna tagar. Hashtag menyediakan suatu cara untuk mengelompokkan pesan tersebut, karena pengguna lain dapat mencari hashtag dan mendapatkan seperangkat pesan yang mengandung hashtag yang sama.

Penggunaan hashtag sendiri digunakan oleh RR Outdoor Gear sebagai strategi pemasaran dalam memasarkan produknya. Caranya adalah dengan membuat kata kunci yang mudah dicari oleh pengguna lain. Setiap unggahan baik foto maupun video selalu diberikan hashtag yang berkaitan dengan unggahannya. Misalkan mengupload kegiatan pendakian digunung Arjuna, maka hashtag yang digunakan juga \#arjuna. Ini digunakan agar pendaki yang mencari gunung arjuna melalui media instagram akan terarahkan ke akun rroutdoorgear_official, tetapi dari keseluruhan hashtag yang sering dipakai adalah \#rr_triporganizer dan juga hashtag \#rroutdoorgear_catalog. Fungsi memperbanyak hashtag agar pengguna/konsumen yang akan melakukan pencarian di instagram mudah untuk menemukan akun rersmi instagram RR Outdoor Gear.

Secara keseluruhan dalam penggunaan hashtag dalam setiap unggahan foto maupun video yang dilakukan oleh RR Outdoor Gear memiliki tujuan diantaranya yaitu untuk mempermudah pengguna lain untuk menemukan akun RR Outdoor Gear, Strategi ini juga berlaku jika ada pengguna instagram lain (bukan followers dari RR Outdoor Gear) ingin mencari atau membeli produkproduk gunung di instagram, mereka cukup mencarinya dengan hashtag nama barang yang diinginkan. 
Dengan begitu produk-produk yang dijual oleh RR Outdoor Gear bisa muncul.

RR Outdoor Gear juga memanfaatkan insta story untuk dijadikan strategi memajang produkprouduk yang dijual. Insta story berasal dari singkatan Instagram Stories. Insta story bisa memposting berbagai foto atau video yang tidak muncul di halaman profile dan bakal terhapus dalam waktu 24 jam. Dalam insta story RR Outdoor pada akun rroutdoorgear_official sering juga mengupload aktivitas keseluruhan bisnis diantaranya adalah penjualan, persewaan, perbaikan dan trip organizer. Karena insta story bersifat hanya sementara (24 jam) maka RR Outdoor Gear sering memposting foto atau video agar insta story tidak kosong. Tujuan sering membuat insta story agar konsumen atau pengguna lain percaya bahwa akun tersebut merupakan akun resmi dan aktif.

Insta story yang membuat foto atau video yang diposting tidak bisa bertahan 1 hari lebih, membuat RR Outdoor Gear memanfaatkan fitur highlight. Fitur ini adalah fitur yang dapat digunakan menyimpan dan menampilkan daftar stories di profil lebih dari 24 Jam. Dalam highlight atau yang biasa disebut sorotan pada rroutdoorgear_official menampilkan beberapa cerita (foto dan video) diantaranya produk-produk yang dijual, daftar harga sewa peralatan gunung, maupun bisnis trip organizer yang dijalankan oleh RR Outdoor Gear secara keseluruhan.

Strategi lain yang digunakan adalah dengan melakukan DM. Kata DM adalah kepanjangan dari Direct Message yang merupakan salah satu fitur Instagram juga. Fitur DM pada Instagram ini memungkinkan akun RR Outdoor Gear dapat berbagi banyak hal melalui pesan langsung tersebut karena dapat mengirim file teks, foto dan video ke pengguna lainnya. Ini digunakan oleh RR Outdoor Gear untuk menyebar pesan kepada pengikut untuk menawarkan produk-produk yang dijual. Pesan yang dikirim lebih bersifat pribadi karena langsung masuk ke inbox akun yang disasar. DM yang dilakukan lebih memungkinkan juga untuk langsung dibaca oleh akun yang telah dikirimi pesan. 


\section{KESIMPULAN DAN SARAN}

\subsection{Kesimpulan}

Kesimpulan yang diperoleh adalah bahwa strategi pemasaran RR Outdoor Gear melalui akun instagram rroutdoorgear_official dilakukan dengan menggunakan fitur-fitur instagram diantaranya strategi posting produk, penggunaan hashtag, penggunaan insta story (highlights), serta menggunakan cara DM (Direct Message). Fitur yang ada dalam instagram tersebut dijadikan alat RR Outdoor Gear dalam memasarkan produk yang dijual, baik penjualan barang (pakaian/perlengkapan alat-alat

\section{DAFTAR PUSTAKA}

Alma,

Buchari.

2014.

Kewirausahaan. Bandung : Alfabeta.

Cannon, Joseph, William Perrcault, dan Jerome McCarthy. 2009. Pemasaran Dasar 2. Edisi 16, buku ke-2. Jakarta : Salemba Empat.

Helianthusontri, Jefferly. 2020. Instagram Marketing Untuk Pemula. Jakarta : PT Elex Media Komputindo.

Hidayatullah, Achamad. 2018. Digital Learning. Surabaya : UM Surabaya Publishing.

Hutahayan, Benny. 2019. Peran Kepemimpinan Spiritual dan Media Sosial Pada Rohani gunung), maupun penjualan jasa (persewaan, reparasi/perbaikan, dan trip organizer).

\subsection{Saran}

1. Bagi perusahaan hendaknya rutin memaksimalkan fitur yang lain seperti IG TV, atau bisa menggunakan iklan.

2. Bagi akademisi selanjutnya bahwa penelitian ini hanya sebatas tentang pemasaran melalui media sosial instagram. RR Outdoor juga menggunakan media sosial lain yang bisa dikaji bagi akademisi selanjutnya.

Pemuda di Gereja Batak Karo Protestan (GBKP) Cililitan. Yogyakarta : Deepublish.

Ibad, M Nashoihul dkk. 2020. Bisnis UMKM Ditengah Pandemi. Surabaya : Unitomo Press.

Kotler, Philip dan Gary Armstrong. 2008.

Prinsip-Prinsip Pemasaran. Edisi 12, Jilid ke2. Jakarta : Erlangga.

Nofriansyah, Dicky dkk. 2020. Bisnis Online : Strategi dan Peluang Usaha. Medan : Yayasan Kita Menulis.

Politwika. 2015. 99 Cara Super Lesatkan Bisnis Via Social Media. Jakarta : Grasindo. 
Rahmat, Pupu Saeful. 2019. Strategi Belajar Mengajar. Surabaya : Scopindo Media Pustaka.

Saleh, Muhamad Yusuf dan Miah Said. 2019. Konsep dan Strategi Pemasaran. Makassar : CV Sah Media.

Stiletto, Tim dan Ranny Afandi. 2019. How To Win Instagram. Yogyakarta : Stiletto Book.

Sudibyo, Agus. 2019. Jagat Digital. Jakarta : Kepustakaan Populer Gramedia.

Sukoco, Sampir Andrean. 2018. New Komunikasi Pemasaran Teori dan Aplikasinya. Jember : CV Pustaka Abadi.

Sulianta, Feri. 2015. Keajaiban Sosial Media. Jakarta : PT Elex Media Komputindo.

Supardi, Yuniar. 2009. Internet Untuk Segala Kebutuhan. Jakarta : PT Elex Media Komputindo.

Suratman, Bambang, dkk. 2019. Kiat Sukses Pemasaran Online Bagi Petani. Sidoarjo : Zifatama Jawara. 